\title{
The Kind of Writing
}

\section{Anthropology and the Rhetorical Reproduction of Postmodernism}

\author{
Albert Doja \\ University of Limerick, Ireland and University College London
}

Abstract In a now much-read critique, Derrida claimed to show the weakness and the supposed contradictions of Lévi-Strauss's interpretation of writing and his characterization of modern industrial society by the pathology of written communication. Lévi-Strauss is tweaked however for everything at odds with what is normally understood as Lévi-Straussian analysis. It is my contention in this article to argue that, by misconstruing Lévi-Strauss's actual theoretical and epistemological contribution to general knowledge, Derrida's reading of Tristes Tropiques is exemplary and influential in that it joins together all the essential didactic elements of 'deconstructionist' criticism, and seems to be what exactly 'lit-crit' deconstructionism is all about, which in the last analysis turns into an arrogant scholastics that only ignorance or deliberate misinformation could allow.

Keywords — criticism — deconstruction — Derrida — Lévi-Strauss — writing

In Lévi-Strauss's distinction between hot and cold societies, when it comes to the question of the causation of the divergences, the different strands of analysis all point to one specific phenomenon. In non-literate, so-called 'primitive', non-civilized or non-industrial societies, interpersonal communication is more proximate and more immediate than in modern societies, where, by contrast, relationships between individuals in literally every sphere of modern social life - interpersonal, administrative, political - are intermediate rather than immediate, inasmuch as they are at least mediated through written documents.

Our relationship with our own past is a similarly indirect and mediated experience, accessed through the written archive and administrative machinery, which undoubtedly vastly extend our contacts but, at the same time, unlike a living oral tradition, give those contacts some kind of 'inauthenticity' (Lévi-Strauss, 1958: 400-1 [366]). ${ }^{1}$ And the extension of the mass media has only added to the catastrophic loss of autonomy experienced by the modern individual. So if society was to be defined as a system of communication, then Lévi-Strauss's diagnosis of modern industrial society is that it is characterized by a pathology of communication. More specifically, the modes of technological development and historical consciousness that Lévi-Strauss takes to be responsible for the destructive 
expansion of Western civilization would be impossible without the defining technology of writing (Lévi-Strauss, 1961: 28-9 [26-27]).

Yet Lévi-Strauss's treatment of writing, using the case of Nambikwara mimicry as symptomatic, both enhanced and undermined his case for anthropology as an inclusive science. It enhanced it through showing that the imposition of written language is coincident with hierarchization and other shortcomings of modernity or a 'hot' society. It subverted it by providing an entrée for free-floating philosophical speculation of the genus poststructuralism and postmodernism that ignores the broader anthropological project. In this respect, we must revisit Derrida's now classic reading of LéviStrauss on writing, and, in what follows, I would argue - against most postmodern commentators and critics - that this influential reading has got it wrong, that it has misrepresented Lévi-Strauss's epistemological enterprise and his humanistic mission.

Many of Derrida's arguments on this point do not hold up under a close analysis, and it seems necessary to tease out the inconsistencies and show that Lévi-Strauss's position on this, as on most other things, is far more complicated and nuanced than the version of it presented by Derrida. In this debate Lévi-Strauss has been quite oddly and undeservedly accused variously of being unethical in his fieldwork, of failure to subject his material to analysis, of ethnocentrism, subjectivism, empiricism, truism, archaism, primitivist utopianism, epigenesism, sloppy thinking, non-sense, theology and metaphysics - in short, of everything that is at odds with what normally stands as Lévi-Straussian analysis.

In a central period in anthropological history, when in Lévi-Strauss's hand the mental and the material were granted equal space, there was a strong programmatic claim for an expansive scientific approach, but the rendering of that problematic was restricted as other brands of structuralism came to dominate the centre stage. Eventually, as I will show elsewhere (Doja, 2006b), the debate must be situated in its intellectual context of the struggle over the academic division of labour in the 'postmodern cultural condition'.

Lévi-Strauss's thinking on issues that mattered to him was anything but linear and simple. Nevertheless he is highly esteemed as a scholar who never shied away from answering critics. Most of his rejoinders are now exemplary pieces of critical literature and some of his one-liners proverbial. He would also at times revise ideas, when he felt the criticism to be serious and powerful enough. Surprisingly, to the best of my knowledge, there has been almost no argued reply to Derrida's criticism. I even had the opportunity to ask Lévi-Strauss himself directly about this. Not surprisingly, he replied as usual, in his typical laconic style: 'You explain excellently elsewhere [referring to Doja, 2005, 2006a] that I always refused to enter certain debates and why. However, it seems that it is exactly what you are asking me to do. I am not prepared to do more today than yesterday' (Lévi-Strauss, personal communication, 19 July 2004). In a letter addressed to the editors 
of the Cahiers pour l'Analyse, where Derrida's chapter was first published (1966[4]: 1-45), Lévi-Strauss's only reaction was to acknowledge that he could not get over his embarrassment at his impression that Derrida, by dissecting his ethnographic musings on the field, did no more than 'play a philosophical farce', handling 'the third excluded with the delicacy of a bear' (Lévi-Strauss, 1966[8]: 89)!

Certainly, many anthropologists would now agree that Derrida's deconstructionist project was not one of negating or demolishing structuralism, but more one of pushing structural anthropology to its most radical potential. The problem, however, is rather that Derrida's critique often seems to have served as an excuse for many not to read Lévi-Strauss or engage with the highly problematic and subtle nature of his thought on its own terms. 'Post-structuralist' litterateurs, meanwhile, have been inspired by this muchread critique, sometimes as an absent referent, which is simply taken as the last word on Lévi-Strauss and structuralism, and they simplistically assume that structural analysis had therefore been superseded. To a certain extent, more often than not this line of criticism seems to be less a matter of bold arguments against Lévi-Strauss's theory than a matter of a dogmatically antistructural ideological posture, which relies on the received ideas of many 'lit-crits' and 'post-crits' alike derived from the excessive coverage of a very often unfounded critique.

The point here is not to conflate Derrida's reading of Lévi-Strauss with post-structuralism and postmodernism, which would be an anachronistic misconstruction, to the extent at least that the very terms 'post-structuralist' or 'postmodernist' were never used by Derrida. There is, nevertheless, an increasing dissatisfaction and impatience with what post-structuralist and postmodernist criticism has become in the wake of Derrida. I believe that making a case for the inadequacy of Derrida's argument may also go some way toward recovering Lévi-Strauss from the undeserved intellectual obsolescence he seems to have been consigned to since then.

\section{The scene of writing}

In the celebrated chapter of Tristes Tropiques on the 'writing lesson', LéviStrauss described the violent irruption of writing in Nambikwara society (1955: 339-45 [296-300]). When the Nambikwara chief crudely mimicked the act of writing, imitating the ethnographer recording his notes, it was in order to discover its function of subjugation.

Writing had made its appearance among the Nambikwara but not, as one might have imagined, as a result of long and laborious training. It had been borrowed as a symbol, and for a sociological rather than an intellectual purpose, while its reality remained unknown. It had not been a question of acquiring knowledge, of remembering or understanding, but rather of increasing the authority and prestige of one individual, or function, at the expense of others. (1955: 341-2 [297-8]) 
The 'writing lesson' became the target of Derrida's 'violence of the letter' (1967a: 149-234 [101-40]), that classic reading with its no less classic verbosity, which attached such a great importance to the least alleged disproportion between factual certainties and their interpretive reconsiderations, and claimed to reveal Lévi-Strauss's purported inconsistencies and contradictions, whatever they might be.

It must be noted, first, that Derrida's reading is exemplary in that it joins together all the essential didactic elements of 'deconstructionist' criticism, and seems to be exactly what 'lit-crit' deconstructionism is all about. It is unnecessary to recall here the analytical philosophers' tendency to scorn what they see as the 'textualizing' tendencies of literary critics, who in their view dissolve major philosophical issues like truth, reference and even meaning into an opaque solution of arcane metaphysics and postmodern mumbo-jumbo. But, certainly, the actual style of Derrida's own writing, in this instance as in others, is highly rhetorical, complicated by a penchant for paradoxical formulation and various forms of often wilful wordplay, revealing nothing more than the actual exuberance of his own logorrhoea and logomachy. Its first merit, and undoubtedly the only one that explains the considerable influence of deconstruction in the field of literary criticism, is to be very sensitive to the literary quality of Lévi-Strauss's text, to emphasize how much Lévi-Strauss's argument depended on the construction of a narrative and on the performance of a drama.

Having underlined at considerable length the rhetorical and narrative dimension of Lévi-Strauss's 'writing lesson' episode, showing how the theory of writing is seemingly demonstrated and justified before its actual enunciation, Derrida then went on to argue that Lévi-Strauss's parable of writing is an uncertain and ambiguous episode based on a fiction involving the chief's subterfuge, which Lévi-Strauss described as an 'extraordinary incident' but which, for Derrida, was a simple fictional use or abuse of writing. He then exposed, with great effort, the disjunction that he believed he was locating on the logical level between fact and theory.

The most serious split appears first between the meagre fact of the 'extraordinary incident' and the general philosophy of writing. The point of the incident in effect supports an enormous theoretical edifice. (Derrida, 1967a: 184 [126])

The fact of imitating without understanding - since the Nambikwara chief used writing effectively without knowing the real origin of real writing as it would have naturally evolved over time within a given social and cultural space, neither the way it functioned nor the content signified by it - according to Derrida (1967a: 184-5 [126-7]), is a truncated and caricatured representation of the use of writing, which is said to 'open and cover the entire space within which Lévi-Strauss is now going to think writing' and in effect allow him to demonstrate its end as political and not theoretical, 'sociological, rather than intellectual'. The supposed weakness of LéviStrauss's argument is thus said to lie in the inconsistency of his theory of 
writing, which, Derrida maintained, shows his empiricism and his precipitate judgement, mistaking the empirical for the essential.

Siding with the philosophers of consciousness, Descartes, Husserl and Bergson, who are only evoked and incriminated in Tristes Tropiques as caricatures, Derrida insisted that: 'the difference between empirical affect and the structure of essence was for them a major rule', and that none of them 'would ever have suggested that they considered an empirical modification of their relationship with the world or with others as scientific truth, nor the quality of an emotion as the premise of a syllogism'. Never would a rigorous philosopher of consciousness have been 'so quickly persuaded', as Lévi-Strauss purportedly is, 'of the essential goodness and virginal innocence of the Nambikwara merely on the strength of an empirical account or a subjective and personal experience' (Derrida, 1967a: 172 [117]).

There is certainly a crude contradiction here, inasmuch as Lévi-Strauss is, rightly or wrongly but nevertheless systematically criticized, albeit not by Derrida, for the way he marginalizes questions of subjectivity in his analyses. On the other hand, Derrida's influence on what is now known as the postmodern turn to subjectivity is deemed tremendous. Now, if Derrida himself claims the contrary, blaming Lévi-Strauss for his overemphasis on intersubjectivity - that is, exactly what modernist writers are praised for - the contradiction is not necessarily within Lévi-Strauss.

The strategic importance of Tristes Tropiques in Lévi-Strauss's work, with its tellurian images of a 'mental ground' (Campion, 1996), has been to transport otherness and the reality to be known into the self, by entrusting the mind and its own time with an activity of structuring the world and the time of the world, which makes the world recognizable in and by the mind itself. At the same time, while relating the knowledge of this real and separate world to the knowledge of self, an epistemological problem is solved, an intellectual uneasiness is dissipated and an ontological pain is soothed, that of the separation of subject from the object, of self from the other.

The identification of self and other, which Lévi-Strauss seized through Rousseau to found his vision of anthropology, is made possible by the parallelism, founded in kind, between the symbolic character of cultures and the imaginary character of memory. It becomes a test of the humanity within oneself and constitutes the very principle of a differential anthropology. All that apparently disconcerted Derrida and many others, but, in LéviStrauss's view and epistemology, this is neither self-satisfaction nor a literary artifice, but one of the conditions of validity of a scientific approach in anthropology. One will understand, then, how and why certain facts of intersubjectivity can be used in support of a theoretical edifice to provide a general philosophy of writing.

Derrida tried to show the fragility and over-simplification of LéviStrauss's assumptions on the place and function of writing in the history of societies and civilizations. Yet, ultimately, he could not refute Lévi-Strauss's 
argument concerning the association of writing, hierarchization and exploitation (Derrida, 1967a: 190 [130]). Lévi-Strauss's further speculations on the historical function of writing, and its role in social and cultural change, seem to be a logical consequence of a series of assertions, which come as a kind of theoretical commentary and moral coda on the "extraordinary incident' described in the scene of 'writing lesson'. Developed further, among other instances in the broadcast Conversations (Lévi-Strauss, 1961), they become effectively a quite coherent and compelling theory of writing.

Derrida pointed out that Lévi-Strauss's attempt to distinguish between the intellectual and sociological functions of writing, to dissociate the possibility of scientific progress from the technology of written communication, is the necessary precondition of his hypothesis concerning the oppressive and exploitative function of writing. Perhaps the only thing to blame may be that this sociological necessity, which is that of 'domination', 'exploitation', 'enslavement' and 'perfidy', according to Derrida, would be a poor truism and would have little enough to do with the sociological specificity of writing.

These facts are well known. It has long been known that the power of writing in the hands of a small number, caste, or class, is always contemporaneous with hierarchization; it is at the same time distinction into groups, classes, and levels of economico-politico-technical power, and delegation of authority, power deferred and abandoned to an organ of capitalization. This phenomenon is produced from the very onset of sedentarization, with the constitution of stocks at the origin of agricultural societies. (Derrida, 1967a: 190 [130])

So far, so good! Even though this is clearly a Lévi-Straussian language, perhaps in Derrida's mind such an argument would require some qualification. Lévi-Strauss's affirmation that the period between the invention of writing and the expansion of modern science in the 19th century was a period of relative stagnation, in which the quantity of knowledge fluctuated rather than increased, is then criticized for its empiricism, for it poses an essentially unverifiable question and fails to ask the properly essential question that Derrida had in mind concerning the nature of learning and knowledge. The distinction of the 'sociological' from the 'intellectual end' is also said to be problematic, only because Derrida (1967a: 185 [127]) cannot see what restricts the impact of the potential of violence, which is inherent to the political but not the theoretical end of writing.

According to Derrida, in his haste to prove that the appearance of writing inevitably entails the corruption of authentic human intercourse, Lévi-Strauss failed to ask the fundamental question regarding the nature of the object he was describing, taking as immediately clear and self-evident that he and his reader know and understand what writing is. But if it is true, as Derrida himself also believed, that writing cannot be thought outside of the horizon of intersubjective violence, is there anything, even an emotional feeling, for which one must radically blame Lévi-Strauss? As long 
as there is not 'a knowledge and above all a language, scientific or not, that one can call alien at once to writing and to violence', why is 'Lévi-Strauss's use of these concepts to discern the specific character of writing not pertinent', as Derrida claimed? Perhaps, if 'all the examples by which LéviStrauss next illustrates this proposition are of course true and probing, but too much so', this is simply because the conclusion that they sustain goes far beyond the field of what Derrida (1967a: 186 [127]) must have had in mind when he was talking about 'writing'!

When Derrida aimed at underlining the importance of the historical conjuncture of the question of ethnocentrism - as well as the notion of anthropology as a human science and the idea of a certain 'end' of traditional metaphysics - framed by the still recent experience of post-war decolonization, his criticism problematized the definition of writing by first questioning Lévi-Strauss's distinction between literate and non-literate cultures. Whereas this definition is for Lévi-Strauss necessary to the constitution of the very object of his discipline, Derrida saw in it a symptom of ethnocentrism that anthropology was, perhaps, prematurely pleased to have left behind. Thus he claimed to strike at the heart of the human scientific enterprise as represented by anthropology, whose very object of enquiry was based on this recognition of 'non-literate' cultures, and whose moral and humanistic mission consisted precisely in its critique of ethnocentrism.

Lévi-Strauss's theory of writing is said to commit what one may call an error of punctuation in Bateson's sense (1972: 163), that is, his framing of the context of writing is unduly restrictive, resulting from a limited conceptualization of writing (Johnson, 1997: 29). Derrida's criticism is aimed at Lévi-Strauss's characterization of the Nambikwara, whose level of cultural development is compared with that of people of the Neolithic era, as a 'people without writing'. Lévi-Strauss's assumption that Neolithic culture did not possess a system of writing must be based on a singularly narrow conception of writing, according to Derrida, that is, on Western alphabetical-phonetic writing, which is but one of a whole number of possible systems of notation. To be sure, the Nambikwara do not 'write' in the same way that the ethnographer writes in his note-pad - they visibly do not possess a system of phonetic notation - but Lévi-Strauss is too precipitate, Derrida argued, in his consequent categorization of this people as 'nonliterate'.

An important result of Derrida's deconstruction is to extend the frame of reference around the phenomenon we normally call 'writing'. 'Up to what point is it legitimate not to call by the name of writing those "few dots" and "zigzags" on the Nambikwara calabashes, so briefly evoked in Tristes Tropiques?' Derrida asked (1967a: 161-2 [110]). Not only these decorations, but also the drawings the Nambikwara present to the ethnographer and, more importantly, the genealogical tree sketched on the soil - could not all of these be deemed forms of writing, coding and memorization? 
Actually, 'it is not merely a question of representational designs showing a man or a monkey, but of diagrams describing, explaining, writing, a genealogy and a social structure' (Derrida, 1967a: 182 [124-5]).

Yet, in hurrying to show Lévi-Strauss's precipitateness in his alleged ascription of a purely aesthetic function to the Nambikwara's drawings, Derrida naively seems to believe he was teaching Lévi-Strauss that the normal critical reflex of the anthropologist would be to caution against categorizations of this type. We know, however, from the investigation among the Caduveo, some chapters before the 'writing lesson', that 'the customs of a community, taken as an ordered whole, always form a system marked by a particular style' (Lévi-Strauss, 1955: 203 [178]). While LéviStrauss understands this concept of style first in an epistemological sense, he also retains its aesthetic sense, not only because ethnographic facts and documents of an aesthetic kind are as significant as all other relevant traits of a culture, but also because the very comprehension and observation of these ordered wholes requires the same synthetic procedures that are also at work in the judgement of taste (Campion, 1996: 351).

Thus, Lévi-Strauss's concept of style encompasses the coherent whole of the manifest traits of any culture, both in relation to the unconscious coherence of a creative thought and in the way it is apprehended by a synthetic and intuitive approach of the ethnographer. Ethnographic writing is, above all, the ability to objectively account for the particular style of a culture according to the objectivity of the procedures of that culture's own style. In other words, the ethical and epistemological condition of anthropological knowledge consists in the transposition into the self of the dialectics of the same and the other, of identity and alterity, of the whole and its parts, of innocence and culpability, the universal and the particular, a transposition that dominates the mood and the style of Tristes Tropiques.

Not only did Derrida consider Lévi-Strauss's conception of writing to be narrow, but he also rushed to argue that Lévi-Strauss's far too literal understanding, and his categorization of the Nambikwara from the point of view of Western phonetic writing, his phonocentrism, betrayed an involuntary ethnocentrism. In emphasizing the ambiguity of an ideology that must have governed the Saussurean exclusion of writing, privileging the phonetic model, Derrida (1967a: 176 [120]) argued that the model justifying the exclusion of the graphie must be a profound ethnocentrism that thought itself as anti-ethnocentrism, an ethnocentrism in the consciousness of a liberating progressivism.

If writing is no longer understood in the narrow sense of linear and phonetic notation, it should be possible to say that all societies capable of producing their proper names and of bringing classificatory difference into play practise writing in general. No reality or concept would therefore correspond to the expression 'society without writing'. Finally, for Derrida, 'this expression is dependent on ethnocentric fantasizing, upon the vulgar, that is to say ethnocentric, misconception of writing' (1967a: 161 [109]). 
Convinced that the same ambiguity affected Lévi-Strauss's intentions, Derrida believed that Lévi-Strauss's discourse was affected by a kind of reverse ethnocentrism, which is characteristic of the remorse of the Westerner, and which paradoxically is deemed to be part of the anthropological critique of the ethnocentrism of Western civilization and its creation of a global monoculture. In Derrida's view, the traditional and fundamental ethnocentrism is handled and thought of as anti-ethnocentrism in supporting an ethical and political accusation. 'Man's exploitation by man is the fact of writing cultures of the Western type; communities of innocent and unoppressive speech are free from this accusation' (Derrida, 1967a: 177 [121]).

Arguably, one of the shortcomings of Derrida's reading of the 'writing lesson' and of his own concept of writing is that, ultimately and paradoxically, it flattens the very notion of alterity, an alterity that is precisely represented in the Nambikwara 'scene of writing'. Throughout Tristes Tropiques Lévi-Strauss makes it clear that the anthropologist's projection of his own locale into his subject's is not innocent; it is more active than just a failure of imagination. Even when he carries the Old World with him in the most trivial ways, as when he hums a Chopin melody over and over while marching through the bush (Wygant, 1989), a darker and more potent intrusion is implicit. For his problem as a quester is not that so much remains inaccessible to him, but that so much has already been destroyed (Scobie, 1977: 148). Lévi-Strauss litters his memoir with stories of pathetic and perverse sorts of ethnocentrism and exploitation on the part of adventurers, missionaries, cowboys, bureaucrats and even anthropologists. In questing to leave his own world behind and to encounter social life in its strangeness, the ethnographer is only another contaminator, a cultural analogue to the 17th-century traveller who remarked how free of diseases the Tupi Indians were while 'he did little realize that he and his companions were the forerunners of the carriers of these diseases' (Lévi-Strauss, 1955: 399 [346]). The whole idea of a quest into their world presupposes our having undermined it already. Anthropology arises in a situation where its project of crossing borders is nostalgic and inauthentic. The boundaries have already been crossed, and we find only second-hand versions of ourselves.

Indeed, what would be rather more necessary for the Derridean poststructuralist reader to know is that Lévi-Strauss, by vocation, has become the voice and advocate of indigenous peoples and the subversive critic of his own civilization. Lévi-Strauss is, after all, the person who, with his sense of humanism, reshaped the world's opinion of the much-maligned and much-abused so-called 'primitive' peoples. The creative originality of LéviStrauss in alerting us to the importance and complexity of life and imagination of 'peoples without writing' can hardly be underestimated. The very cultural relativism that the social sciences enjoy today results, for the most part, from the successive Copernican revolutions to which Lévi-Strauss 
subjected kinship and marriage (1967), thinking as a classifying exercise (1962a, 1962b) and the transformational logic of myths (1964, 1966, 1968, 1971). His almost single-handed effort to pay careful attention to the structure of myths, marriage rules and classificatory thought has resulted in a total change in the way in which the cultural life of 'simple' peoples is regarded by people from the metropolitan powers. He taught 'civilized people to get off their high horse and learn with humble lucidity that they too are an indigenous variety' (Finkielkraut, 1987). He deserves full credit for destroying the very concepts of 'primitive peoples' and 'primitive mentality' that had dogged anthropology from its inception.

While, in a tradition of Western cynicism going back to Montaigne, irrationality is deemed to be equally distributed between the people, hence the impossibility of affirming any superiority of one over another, for LéviStrauss it is rationality that is equally distributed among the diversity of cultures, and the task of anthropology is to uncover it (Desveaux, 1992). Without a doubt, in the case of Lévi-Strauss's properly relativistic approach to other cultures, the charge of ethnocentrism is simply out of place. But Derrida did not hesitate to go frenetically in the wrong direction, accusing Lévi-Strauss and his criticism of ethnocentrism of having 'most often the sole function of constituting the other as a model of original and natural goodness, of accusing and humiliating oneself, of exhibiting its beingunacceptable in an anti-ethnocentric mirror' (Derrida, 1967a: 168 [114]).

\section{Rousseauist nostalgia}

Derrida has abundantly held forth upon Lévi-Strauss's ideology of primitivist utopia and his Adamical vision of history, which seem to be deeply rooted in a strong spiritual or ideological affinity with his 'declared and militant Rousseauism' (Derrida, 1967a: 155 [106]). Especially in his other text on the place of 'structure, sign, and play' in the discourse of LéviStrauss and structuralism (Derrida, 1967b: 409-28 [278-93]), published at the same time as the critique in Of Grammatology, Derrida went on to accuse Lévi-Strauss of having neutralized the principles of his own structural approach.

Going back over the chain of various elements attesting to the particularly corrosive character of structural anthropology, Derrida questioned it as to its possible complicity with what he qualified as 'logocentrism'. Gradually, he reconstituted the fabric that he believed held Lévi-Strauss's discourse in a philosophy of another age and that betrayed metaphysical presuppositions. In this way, the structural event was said to be part of a textual chain subjected to the metaphysics of presence in order to assign innocence to the verb and violence to the letter. The structural anthropology of Lévi-Strauss is thus supposed to plunge, flow back towards the 'eighteenth century', towards Rousseau and a certain conception tinged 
with nostalgia for 'natural man'. This reading permitted Derrida to find within the structural discourse the oppositions between play and origin, presence and absence, which he claimed to deconstruct. In contrast, Derrida maintains that Lévi-Strauss consolidates them, especially as he seemed, initially, to threaten them.

When Lévi-Strauss defines the task of anthropology as establishing between societies a scale of 'levels of authenticity' according to the criterion of a more or less widespread use of the written intermediary, it seems to Derrida that he might have been led to define the social only from the fictitious standpoint of a 'self-presence' of the group. Derrida then went on to make the accusation that, by his evocation of the fatal irruption of writing in Nambikwara society, 'by this more or less overt reference to the idea of a fall into evil from the innocence of the word', Lévi-Strauss makes this classical and implicit theology his own. Allegedly, 'his anthropological discourse is produced through such concepts, schemas and values that are systematically and genealogically accomplices of this theology and this metaphysics' that Derrida (1967a: 195-6 [135]) sought to denounce. In the case of Lévi-Strauss, the 'writing lesson' incident only made it possible to negatively determine the essence of a 'self-present' society, which is undisturbed by any arbitrary mark or disruption. What the graphic sign to some extent came to denature is the authenticity of a community hitherto characterized by face-to-face behaviour, the proximity of a shared word, originally good.

Derrida claimed, more particularly, that Lévi-Strauss's a-historicism is another form of fall into metaphysics. He believed he had located in LéviStrauss a nostalgia for transparency and origin which, as with Rousseau, would show that history and progress are associated with the theme of a necessary degradation precipitated by accident and discontinuity. There is a clear and explicit affiliation between Lévi-Strauss and Rousseau, in terms of their respective conceptualizations of how the ideal state or system is disturbed, how it passes from the innocent pure, authentic and immediate, to the corrupt, mediated and alienated. For both Lévi-Strauss and Rousseau, Derrida argued, such a transition is never a natural consequence of the system itself. Rather, it is always precipitated by some external perturbation, some external aggression to the system.

Lévi-Strauss is initially suspected of privileging the movement by which humanity founded the realm of culture. He is thereby said to deduce that no further progress is conceivable. Any event, condemned to lose the savour of its self-presence, can only introduce discordances into a whole petrified by successive sedimentations that these discordances produce, whereas the glamour of the present disappears. The essential specificity of structure is seized only to obliterate time and history, which are thus reintroduced, but in the negative form of rupture and discontinuity. The metaphysics of origin and nature would thus unexpectedly make Lévi-Strauss 'conceive of the origin of a new structure on the model of catastrophe, an 
overturning of nature in nature, a natural interruption of the natural sequence, a setting aside of nature' (Derrida, 1967b: 426 [292]).

In the same way, in the interpretation that he gives of the Rousseauist conception of history, by emphasizing the tone of regret in Rousseau's text, Derrida reveals the negative face of the essential part given to the 'fatal accident' in the play of the world. Rousseau resigns himself to the play, 'he retains its symptoms in the regulated contradictions of his discourse, he accepts it and refuses it but does not affirm it'. And Derrida concludes with this comment, undoubtedly aimed at Lévi-Strauss:

If societies were born of catastrophe, it means that they are born by accident. Rousseau naturalizes the biblical accident. He makes a natural accident of the Fall. But by the same token, he transforms the throw of dice, the luck or checkmate of a player God, into a culpable Fall. (Derrida, 1967a: 367 [260])

As with Rousseau, Derrida claims, the theme of the game of history is projected in the abyss of a sad nostalgia for what Lévi-Strauss called 'the indefinable grandeur of man's beginnings' (1955: 454 [393]).

In the context of this tension with the history, presence and truth of origins, structural anthropology appears to be torn between its reverse and its right side, between its 'saddened, negative, nostalgic, guilty, Rousseauist side' and 'the Nietzschean affirmation, that is, the joyous affirmation of the play of the world and of the innocence of becoming, the affirmation of a world of signs without fault, without truth, and without origin' (Derrida, 1967b: 427 [292]). At best, as with history, in Lévi-Strauss there would be the idea of some 'epistemological break' between Rousseauist discourse and the structural approach, a kind of 'tension' revealing the metaphysical implication of structural reasoning as well as the drama of an individual or collective conscience, in which Lévi-Strauss is said to be taken.

In other words, for Derrida, all the liberating criticisms and legitimate denunciations that Lévi-Strauss uses to attack the presupposed distinctions between historical societies and societies without history are considered to remain dependent on the concept of writing that Derrida sought to problematize. Finally, all this harks back to his criticism of 'a sort of ethic of presence, an ethic of nostalgia for origins, an ethic of archaic and natural innocence, of a purity of presence and self-presence in speech' (Derrida, 1967b: 427 [292]).

In this attack, Derrida seems to believe that Lévi-Strauss supported the implications of the structural perspective with regard to a Utopia of a fully present word that the violence of writing would bring to an end. At the most manifest level, in the 'writing lesson' as in other instances, Lévi-Strauss actually echoes, albeit without referring to it directly, a recurring theme of Rousseau's work: the denunciation of books and a nostalgia for a preliterate society, in which the integrity and authenticity of the spoken word is not as yet corrupted by the mediation of literacy.

Derrida believed the sense of violation that accompanies the scene of 
writing is prepared for and enhanced by the ethnographer's previous characterization of the Nambikwara as essentially good, so that personal ethnographic confession and theoretical anthropological discourse become complicit. It is only by first constructing an idealized image of the Nambikwara as an innocent and simple people that Lévi-Strauss is supposed to be able to offer the 'writing lesson' as an example or parable of the corrupting effects of writing. Derrida then proceeds to question what he calls the 'epigenesism' of Lévi-Strauss's interpretation of the 'writing lesson', that is, the tendentious representation of the 'innocence' of the Nambikwara as the indispensable basis of the distinction between an internal and an external space, respectively 'good' and 'evil'. In the internal paradise of the Nambikwara the appearance of writing, the poisoned gift of civilization, is sudden and spontaneous, an external intrusion and aggression, rather than a development internal to Nambikwara society (Derrida, 1967a: 170-4 [116-19]).

According to Derrida (1967a: 165 [112]), Lévi-Strauss always thinks of empirical violence, of war in the colloquial sense, as an accident occurring upon a terrain of innocence, in a 'state of culture' whose natural goodness had not yet been degraded. The ruses and perfidy of little girls in the socalled 'battle of proper names' are but apparent ruses and perfidy of little girls, for the ethnographer will prove them innocent by showing himself as the true and only culprit. The ruses and perfidy of the Indian chief playing at the comedy of writing are but apparent ruses and perfidy of the Indian chief, for he borrowed all his resources from the Occidental intrusion.

The ethnographer thus becomes simply an unwitting protagonist, representing the corrupting effects of an alien technology on a hitherto harmonious and innocent community. Without writing, Nambikwara society would have remained in a kind of pre-historical state of limbo, an eternal present, blessed in its poverty and its ignorance. With the advent of writing, it enters history, which brings inequality and exploitation. Luckily for Lévi-Strauss, the Nambikwara intuitively sensed the danger of this and abandoned the chief, thereby gaining temporary respite from the encroachments of civilization.

Indeed, taking into account Lévi-Strauss's own ethnographic experience of Nambikwara society, it is perhaps no exaggeration to consider that the primary offence in the incident of the 'writing lesson' is a kind of exploitation, an instrumental rather than an intellectual use of writing, turned to the sinister manipulation of others. Actually, in the Nambikwara village, the insubordinate, strong-minded characters were the most sensible. 'The villagers who withdrew their allegiance to their chief after he had tried to exploit a feature of civilization felt in some obscure way that writing and deceit had penetrated simultaneously into their midst' (LéviStrauss, 1955: 345 [300]).

Those who seceded from the group, therefore, must have functioned as a kind of self-correcting mechanism, a quasi-automatic reflex that 
checked the chief's transgression of the boundary. The unusual foresight and gift of anticipation saw the Nambikwara chief as implicitly assimilated to the civilization that had - directly or indirectly - been the cause of his people's misfortunes. As such, he became both absolutely essential to the political economy of Nambikwara society and potentially a threat to it (Johnson, 2003: 141). For Lévi-Strauss, the justified conclusion was the punishment of the chief's hubris, the subsequent cutting back of his power.

Yet for Derrida, it is the admitted colloquial difference between language and writing, the rigorous exteriority of one with respect to the other, that first permits the distinction between peoples using writing and peoples without writing. This, above all, must have allowed Lévi-Strauss:

... [to] consider the passage from speech to writing as a leap, as the instantaneous crossing of a line of discontinuity, passage from a fully oral language, pure of all writing, that is, pure and innocent, to a language appending to itself its graphic representation as an accessory signifier of a new type, opening a technique of oppression. (Derrida, 1967a: 176 [120])

According to Derrida, Lévi-Strauss needed this epigenesist concept of writing so that the theme of evil and exploitation suddenly coming about with the graphie could indeed be the theme of a surprise and an accident affecting the purity of an innocent language from without and by chance. 'The ideal profoundly underlying this philosophy of writing is therefore the image of a community immediately present to itself, without difference, a community of speech where all the members are within earshot' (Derrida, 1967a: 197 [136]). This model of a small community with a 'crystalline' structure, completely self-present, assembled in its own neighbourhood, is undoubtedly Rousseauistic (Derrida, 1967a: 200 [138]).

Derrida's corrective to the dichotomy of internal and external space involving innocence and corruption, proximity and alienation, authenticity and artifice, or other similar oppositions, is to suggest that corruption, alienation and artifice are already at work in the system, that they are part of the system and inherent to its dynamic, but are projected outside the system described. What in effect should be considered as native to a system, essential to its very existence and persistence, here 'writing' and 'violence', is considered an inessential and even dangerous supplement to it. A binary opposition is therefore posited between a pure, inner core and origin supposedly in language and voice, and the externalized mediation of this core or origin through writing.

Derrida admits, however, that this kind of projection is not peculiar to Lévi-Strauss. For the militant critics, a written language can, of course, be a powerful tool of enslavement, but it can also serve the cause of liberation; Rousseau's own texts bear witness to a nostalgia precisely balanced by his respect for 'natural' inevitable historical progress (O'Hagan, 1978: 33). Derrida went on nevertheless to argue that Lévi-Strauss's purported selective restriction of writing to its Western alphabetic-phonetic variant must be 
only a function of his 'desire' that there exist an innocent and ideal community untouched by the script, and, in contrast, a pervasive and corrosive civilization whose power and science is dependent on it. If this were the case, however, one might wonder why one should simplistically assume Lévi-Strauss's 'desire' for innocence only and neglect the very fact of corruption by means of that Western alphabetic-phonetic writing which Derrida ultimately cannot deny. Indeed, if we read Derrida and if written words have a meaning, 'Rousseau and Lévi-Strauss are not for a moment to be challenged when they relate the power of writing to the exercise of violence' (Derrida, 1967a: 156 [106]).

If Derrida is to be believed, we must understand that Lévi-Strauss thoroughly presented 'the Nambikwara not knowing violence before writing, nor even hierarchization, since this is quickly assimilated into exploitation'. Yet:

... round about the Lesson, it suffices to open Tristes Tropiques at any page to find striking evidence to the contrary. We are dealing here not only with a strongly hierarchized society, but with a society where relationships are marked with a spectacular violence.

Paradoxically, the quote is not Lévi-Strauss's, nor from any of the commentators, but is from Derrida himself (1967a: 196 [135]).

Indeed, Lévi-Strauss is undoubtedly not unaware that the Nambikwara are at the same time good and malicious, and the perfidy that entered among them with the use of writing is only one of the forms that they already practised in other aspects. It is even likely that their instability, and consequent reliance on individual acts of consent, must have come from the historical conditions that Lévi-Strauss had spoken of earlier. Their population has been decimated by white-carried diseases over the previous century so that the bands are only a tiny fraction of their former size. It seems likely that the older bands would have had more stability and a more hierarchical distribution of authority.

Nambikwara archaism seems illusory, of course, and there seems to be a disjunction between literary declaration and ethnographic description in Lévi-Strauss's text, attributing general significance to what might be better explained within a specific historical context. On the other hand, this experience reveals the insufficiency of an at once empirical and analytical approach. Neither elementary social organization nor radical strangeness are likely to be immediately apprehended. In the case of Nambikwara, it appears that this 'society of the beginnings' cannot be seized in vivo, which is hardly surprising insofar as the experience is diffracted in a series of intersubjective relations. Trying to understand the principle of Nambikwara chieftainship, the anthropologist could only fall back on 'these fugitive nuances of personality which escape analysis' and, seeking a society, end up finding 'only humans'. Indeed, they offer after all the image of this hypothetical state of nature, the fictitious character of which Rousseau was not 
unaware, but which only makes it possible to think the cultural and social history of humankind.

Whatever the case, even though Lévi-Strauss might have declared that his Nambikwara are good, what he actually described in the text of Tristes Tropiques is a society of a hierarchized social structure, marked - like all societies - by both structural and interpersonal violence. Again, in Derrida's own terms:

... the entire Writing Lesson is recounted in the tones of violence repressed or deferred, a violence sometimes veiled, but always oppressive and heavy. Its weight is felt in various places and various moments of the narrative, in LéviStrauss's account as in the relationship among individuals and among groups, among cultures or within the same community. (Derrida, 1967a: 157 [107])

Indeed, not only is Derrida clearly in contradiction with all his own charges - and he even admits here quite the contrary - but any description in Tristes Tropiques should have prevented anyone like Derrida from making similar charges. Some chapters before the 'writing lesson', for instance, are the description of an 'indigenous society and its style' (LéviStrauss, 1955: 203-24 [178-97]) is up to the point. The description of the body decorations of the Caduveo at least seems to share the same discursive framework as the writing lesson, since the social relations and the art of the Caduveo show that they are clearly prone to both writing and violence. In this case as in others, it is an 'arch-writing', to use Derrida's term, a break, a trace in any case, of which Lévi-Strauss reveals the principle, inscribed at the deepest level of the group. One wonders, therefore, how Lévi-Strauss can be suspected, as Derrida (1967a: 195 [135]) did, of supporting his proposition 'by the myth of myth, by the myth of a speech originally good, and of a violence which would come to pounce upon it as a fatal accident'. But Derrida did not mention the Caduveo and their body decorations.

The main aim of Derrida's reading of Lévi-Strauss seems to be to treat his work at all costs as wildly conflicting and deeply at odds with itself. Numerous commentators on Lévi-Strauss stubbornly claim to locate discontinuities in his work. What seems odious to these critics - who are incapable of grasping the structural coherence of Lévi-Strauss's approach - is not structuralism per se or the notion of depth analysis, but rather the claim to an inclusive structural anthropology. They accept structural analysis as unobjectionable when the anthropologist looks at the idea of borders and grants social forms enough integrity to resist easy classification, taking LéviStrauss's analysis of Caduveo face-painting or Bororo social classes as good examples of this (Scobie, 1977: 150). But when Lévi-Strauss claimed the capacity to universalize through depth analysis, they suppose he was presuming the autonomy of each society to be no more than superficial, simply identifying them, without answering the question of relating us and them. 
Arguably, the fundamental point, however, is that there is not an essential irreducibility between structural analysis and its humanistic vocation, just as there is not between the analysis of the body blazons of the Caduveo and the evocation of the 'extraordinary incident' of the writing lesson among the Nambikwara. To maintain a kind of incommensurability - which would be related to Lévi-Strauss's fulfilment of the methodological requirements of structural analysis in one case while departing from it altogether in the other, as Delruelle (1989: 123-4) quite simply believed - is to naively reintroduce Derrida's fallacies.

We must not lose sight of the fact that Tristes Tropiques is not a simple literary artifice, but a structural anthropology. Its composition, fully fulfilling the requirements of structural method as the principle of realizing the world in the mind, unceasingly organizes either explicit or allusive references between parts and chapters. Thus, melancholy appears consubstantial with ethnographic discovery and a range of paradigms come in a variation of successive forms. As much a travel narrative as a report of a search for origins, the book reads like a series of revelations, of an almost mystical nature, involving the great lessons one may expect from anthropology. Among the cultures under consideration, the description of the Caduveo stresses the artistic productions and the concept of style through the structure of body paintings and facial tattooing; the description of the Bororo focuses on cosmological dualism and mythico-ritual systematics through the analysis of dwellings and rituals; that of the Nambikwara the essential social bond and equivalence between trade and warfare through the analysis of family and political structures; finally, that of the Tupi shows the dissolution of a culture.

It is striking to observe in this respect how Lévi-Strauss's work tackles and resolves, one after the other, the theoretical problems posed by such questions, either immediately or in other parallel and later writings, as Geertz (1988: 32) put it, not lineally or quantally, but centrifugally. One cannot help thinking here of the theory of the poetic function of language, following Roman Jakobson (1960), as it has been transposed to the syntax of narrative. In this sense, the overall meaning of Tristes Tropiques is well constructed in a syntactic conjunction of discrete elements, by projecting the analogical axis of paradigmatic substitutions of notions, cultures, times and places onto the digital axis of syntagmatic combination of diverse narrative and reflexive developments which put all in motion.

\section{The battle of proper names}

At the same time as he believed he was deconstructing Lévi-Strauss's theory of writing, Derrida increasingly advanced what in essence is his own theory of writing. Questioning, as he did, where and when writing begins, he located an essential writing, and an essential violence, at a level of 
determination that he believed to be more general and more abstract than that described in Lévi-Strauss's scenes of the 'battle of proper names' and the 'writing lesson'.

Derrida wanted his deconstruction not to be reduced to a simple reversal of views, but situated within a displacement of the very definition of writing. He accepted Lévi-Strauss's association of violence and writing, but he claimed a model of writing that extended both the empirical and the structural field of writing to occupy a terrain wider than that of conventional scriptural systems and that operated at a level of determination deeper than that of empirical writing, indeed, at the level of the very principle and condition of possibility of empirical writing and of language in general. To the empirical violence described by Lévi-Strauss, violence that is supposed to threaten from outside the harmony of the indigenous microsociety, Derrida opposed the structural, differential violence, already at work in this society, the violence that would be the condition of any social system.

Anterior to the possibility of violence in the current and derivative sense, the sense used in the Writing Lesson, there is as space of this possibility, the violence of the arch-writing, the violence of difference, of classification, and of the system of appellations. (Derrida, 1967a: 162 [110])

From the concept of the proper name, which Derrida claimed to be unproblematized in the passage he aptly called 'the battle of proper names' preceding the scene of the 'writing lesson' in Tristes Tropiques (Lévi-Strauss, 1955: 317-18 [278-9]), he felt himself right in saying that the concepts of violence, ruse, perfidy or oppression, which punctuated the 'writing lesson', were also unproblematized. Violence here does not unexpectedly break in all at once, starting from an original innocence whose nakedness is surprised at the very moment when either the secret of the so-called proper names is violated or writing is mimicked. The structure of violence and its possibility in writing must be more complex.

Indeed, the proper name is far from a simple and manageable entity. There is in fact a first violence in being named. Within the Nambikwara social system, Derrida argues, the so-called 'proper names' have already been subjected to the violence of their obliteration, in their consignment to a secret system of classification. To name, to give names that, on occasion, it is forbidden to pronounce, such is the originary violence of language which consists in inscribing within a difference, in classifying, and in suspending the absolute vocative (Derrida, 1967a: 159 [109]).

According to Derrida, Lévi-Strauss's conceptualization of difference in language is phonocentric, while his own conceptualization of difference, in purported contrast to that of Lévi-Strauss, is grammatological, predicated on a particular conception of writing, which allegedly allows him to think precisely the category of violence that characterizes this fundamental process. It is impossible indeed to think of a difference, of a system of 
differences, without the preliminary instance of their inscription, which involves an alteration of a hitherto undifferentiated 'space', in other words, a certain 'violence' done to it.

This is clearly not 'violence' in the everyday sense of the word. Rather, it is the violence of a preliminary coding process without which systems of differentiation like the Nambikwara system of appellations could not exist. Writing, in the common, everyday sense of the word, dependent as it is on the inscription of a surface, the violent incision and separation of a medium, functions therefore as a model of this more fundamentally violent inscription that Derrida called 'arch-writing'. Writing, hence obliteration of the proper classed in the play of difference, is the originary violence itself, that is, the "pure impossibility of the vocative mark, impossible purity of the mark of vocation' (Derrida, 1967a: 162 [110]).

If this arch-violence is forbidden, it is because it is confirmed by a second violence that is reparatory, protective, instituting moral standards, prescribing the concealment of writing and the effacement and obliteration of the so-called proper name that was already dividing the proper. Therefore the second level of violence Derrida delineated in his commentary on the 'battle of proper names' is that of censorship, the covering over and effacement of the system of proper names instituted at the primary level. This is the instance of Nambikwara law, the interdiction of the utterance of the proper name, its violent consignment to secrecy. Again, in its invisibility, in its non-manifest operation, this is not violence in the common sense of the term, but 'structural' violence, inherent in the implicit social codes and classifications that regulate individual and collective behaviour and which are only made manifest through their violation (Derrida, 1967a: 164 [111]).

Such censorship is the precondition of the third and final level of violence, the manifest scene of violation, the ethnographer's indiscreet uncovering of what has been covered over. This third violence is what Derrida terms empirical violence, which may or may not supervene upon the two co-implicated levels of arch-violence and law. It reveals the primary institution of the system of proper names, which is already an expropriation, and the censorship of that institution, which precedes that empirical violence. This Derrida links with the violence of the 'writing lesson' that is to follow, the chief's subterfuge, his appropriation of writing and alleged expropriation of his people, which is a purely fortuitous and contingent, rather than structural violence.

The three-sequence face of violence, as identified by Derrida in its relation with temporal structuring of the social dynamic, is the passage from the fluid existence of the thing in itself to the representation and fixation of the thing through writing/violence that takes away the thingness of the thing. In simpler words, the formation of any meaningful representation, the basis of culture in its anthropological sense, constitutes primordial violence. The second sequence is the violent erasure of the traces of 
this primordial violence, which is usually called law of reason. This counterviolence asserts itself as non-violent and gives itself the power of qualifying subsequent violence. It rules over the third type of violence, the mundane and viscerally horrifying violence. It is the axiological relation between these three sequences of violence that is most important in understanding why some horrifying violence is deemed horrifying, while other violence is considered lawful, reasonable, or even not perceived at all as violence but as normal activity and fact in conformity to the norm.

It is clear that, behind his much acclaimed rhetoric, what Derrida was presenting in his critical commentary of Lévi-Strauss's scene of writing is a structural definition of the proper name and the structural violence of classification systems which, Derrida (1967a: 159-60 [109]) reminded his post-structuralist readers, Lévi-Strauss himself subscribes to in other parts of his work. Certainly, Derrida is conversant with Lévi-Strauss's works and cross-references them in his reading of Tristes Tropiques. What he fails to recall, however, is that, if perhaps he didn't learn all this from Lévi-Strauss, at least Lévi-Strauss's work is essentially dedicated to systems of classification. Not surprisingly, Lévi-Strauss's analysis of the proper name in particular is layered at such a level of sophistication that we are presented with nothing less than a proper theory of names, which is beyond the scope of this article, but which at any rate clearly moves far beyond Derrida's pastiche. Unfortunately, in the trials and tribulations of his later engagement with philosophers of language about proper names, Derrida failed to take any further account of Lévi-Strauss's theory. Seemingly, he must have been comforted in his conviction that literary critics, and perhaps analytical philosophers, did not and probably will never know what the central chapters of Lévi-Strauss's Savage Mind (1962b: 212-86 [161-216]) are all about.

No doubt Derrida's thinking in the 1960s was influenced by structuralism. He acknowledged this influence and recognized the important epistemological contribution of Lévi-Strauss, while he engaged in a very heated game with Lévi-Strauss's work. But using structural anthropology for the purpose of deconstruction meant that the instruments of this deconstruction largely themselves resulted, as Derrida had to recognize, from the structural 'adventure' itself, whether it was 'the sign of an epoch, the fashion of a season or the symptom of a crisis' (Derrida, 1967b: 9 [3]). After all, to use against an entire movement of thought a critical logic that is incontestably at the basis of that movement is somewhat problematic. Derrida obsessively pursued his programme 'of explicitly and systematically posing the problem of the status of a discourse which borrows from a heritage the resources necessary for the deconstruction of that heritage itself' (Derrida, 1967b: 414 [282]). In his desire to deconstruct metaphysics, he was undoubtedly constructing a scholastics of his own. 


\section{Of grammato-logocentrism}

To understand Derrida's fallacy it is necessary to widen the focus of the discussion to consider the task Derrida set himself in his own project of grammatology. If one takes the larger argument of Derrida's grammatology, especially in relation to Husserl's phenomenology with which he was engaged at strictly the same time (Derrida, 1967c), it is clear that the specific materiality of the written form matters very much to him. The point of 'all the investitures to which a graphie, in form and substance, is submitted' (Derrida, 1967a: 132 [87]) is taken up very productively by Friedrich Kittler (1987) in his description of the Aufschreibesysteme of the last two centuries. Yet, as Johnson (1997: 23) pointed out, Derrida is above all interested in the 'desire' that animates that argument, the desire that a binary, black-and-white distinction should exist between speech and writing, the former as the medium of authentic and proximate communication and the latter as the unnatural and violent alienation of the voice.

What falls within his explicit programme, which Derrida called the 'theoretical matrix' of Grammatology, was first to question and contest what he believed to be a Western 'logocentrism', that is, a purported tradition of Western thought in which writing has consistently been cast in a role subordinate to that of speech, with the ambition thereafter to deconstruct the supposed hierarchy between present speech and absent, alienating writing. Whereas speech is habitually associated with reason and rationality (logos) and the voice is perceived as being closer to the inner 'truth' of individual consciousness, guarantor of presence and authenticity, writing is considered to represent artifice and absence, the alienation and deferment of presence, a secondary extension or supplement to the voice, an auxiliary technology employed but not essential to human reason. Whereas speech would be the ideal and immediate mediation of the soul, writing would inhabit the external, corporeal realm of matter.

This perhaps becomes clearer in Derrida's discussion of Saussure than it does in his discussion of Lévi-Strauss, as again he admits the distinction is not explicitly articulated in Lévi-Strauss's text. All this repeats, however, what throughout his book Derrida claimed to be a consistent reflex of logocentric framing necessary to the grammatological Grail he had already constituted. Despite the obvious contradiction with the institutionalized and legitimizing intellectual mastery of writing over local spoken narratives, which will be uncovered later by other postmodern theorists (Lyotard, 1979), it is exactly at the point of its 'theoretical matrix' that Derrida's 'philosophical farce' turns into a postmodern grotesque.

It is evident that speech and voice cannot serve as a model for the grammatological process Derrida claimed. If one posits a traditional logocentric or phonocentric system of representation that opposes speech and writing, speech would be transmitted through the transparent and impressionless medium of air, and would therefore leave no trace. Did Derrida here forget, 
or never know, that the most basic principle of structural analysis is to account for the very fact of difference or systems of differences and not the ways or mediums, whether phonocentric or grammatocentric, in which the difference itself is actualized?

Meaning, and hence violence, to recall a celebrated phrase, 'is that difference that makes a difference' (Bateson, 1972: 272), however defined, described or inscribed it might be, whether in language, writing, naming, genetic code, informational chains, cybernetic circuits, mythic narratives or cosmic objects. That a meaningful difference may go on to become violent is merely an exemplification of Lévi-Strauss's point that this possibility arises from its belonging to a system of differences. This is also Wittgenstein's claim that 'grammar tells us what kind of object anything is' (1953: 353).

In addition, one may quite normally posit a model of violence based as much in an 'arch-writing' as in an 'arch-speech'. The illocutionary power of speech acts, already uncovered by analytical philosophy (Austin, 1962), could perfectly illustrate such an 'arch-speech', if it were. There is no violence without language, not because acts of violence are only words, but because the essential relation between violence and language is a performative one. The differential process that violence institutes necessarily has to have a word, which pretends merely to label, but in reality its performative thrust is to discriminate.

The main thrust of Lévi-Straussian epistemology is to assert that the process of thinking takes place in categories and requires the making of distinctions. Not the content but the very fact of categories and discriminating differences distorts the 'true' nature of the object of thought, and Tristes Tropiques, as Luhrmann (1990: 400) noted, has proved how knowledge destroys the subject of study. Meaning is created by demarcating an undifferentiated environment, by naming, defining, classifying. To know the object is to transform it into a category, that is, to violently differentiate and inscribe for oneself, which is again much more a deep understanding of violence than that described by Derrida.

Simply put, Derrida's distinction between speech and writing is unnecessary, and his opposition of grammatology to logocentrism is just much ado about nothing. Some anthropologists, especially in France, may be ready to dismiss Derrida's discussion of writing as violence, feeling it to be no more than the personal preoccupation of one of the foremost Parisian intellectual dandies. All the fussy logorrhoea is indeed reminiscent of those false celebrities that only the Parisian scene could produce ... and export. In the final analysis, this is no more than an arrogant scholastics and deliberate misinformation that only ignorance or a certain idea of 'selfpresent' grandeur in academy could allow. 


\section{Note}

1 The numbers in square brackets are the page references for the English translations of the works cited.

\section{References}

Austin, John (1962) How to Do Things with Words (William James lectures, 1955). Oxford: Clarendon.

Bateson, Gregory (1972) Steps to an Ecology of Mind. San Francisco: Chandler.

Campion, Pierre (1996) 'De l'anthropologie à la littérature: Tristes Tropiques de Claude Lévi-Strauss', in La Littérature à la recherche de la vérité, pp. 325-35. Paris: Seuil.

Delruelle, Edouard (1989) Claude Lévi-Strauss et la philosophie. Bruxelles: DeBoeck.

Derrida, Jacques (1967a) De la grammatologie. Paris: Minuit. (English trans. Gayatri Spivak. Baltimore, MD: Johns Hopkins University Press, 1976.)

Derrida, Jacques (1967b) L'Écriture et la différence. Paris: Seuil. (English trans., University of Chicago Press, 1978.)

Derrida, Jacques (1967c) La Voix et le phénomène: introduction au problème du signe dans la phénoménologie de Husserl. Paris: Presses Universitaires de France. (English trans., Evanston, IL: Northwestern University Press, 1973.)

Desveaux, Emmanuel (1992) 'Un itinéraire de Lévi-Strauss de Rousseau à Montaigne', Critique: Revue générale des publications françaises et étrangères 48(540): 374-90.

Doja, Albert (2005) 'The Advent of Heroic Anthropology in the History of Ideas', Journal of the History of Ideas 66(4): 631-48.

Doja, Albert (2006a) 'The Shoulders of Our Giants: Claude Lévi-Strauss and his Legacy in Current Anthropology', Social Science Information 45(1): 79-107.

Doja, Albert (2006b) 'The Predicament of Heroic Anthropology', Anthropology Today 22(1).

Finkielkraut, Alain (1987) La Défaite de la pensée. Paris: Gallimard. (English trans., New York: Columbia University Press, 1995.)

Geertz, Clifford (1988) 'The World in a Text: How to Read Tristes Tropiques', in Works and Lives: The Anthropologist as Author, pp. 25-48. Stanford, CA: Stanford University Press.

Jakobson, Roman (1960 [1981]) 'Linguistics and Poetics', Poetry of Grammar and Grammar of Poetry (Selected Writings, vol. 3), pp. 18-51. Hague/Paris: Mouton.

Johnson, Christopher (1997) Derrida: The Scene of Writing (Great Philosophers, 9). London: Phoenix.

Johnson, Christopher (2003) Claude Lévi-Strauss: The Formative Years. Cambridge: Cambridge University Press.

Kittler, Friedrich A. (1987) Aufschreibesysteme 1800/1900. München: Wilhelm Fink. (English trans. Discourse Networks, Stanford, CA: Stanford University Press, 1990.)

Lévi-Strauss, Claude (1955 [1973]) Tristes Tropiques, new edition. Paris: Plon. (English trans. John Weightman and Doreen Weightman, Tristes Tropiques. London: Cape, 1973.)

Lévi-Strauss, Claude (1958) Anthropologie structurale. Paris: Plon. (English trans., New York: Basic Books, 1963.) 
Lévi-Strauss, Claude (1961) In Georges Charbonnier (ed.) Entretiens avec Claude LéviStrauss. Paris: Plon. (English trans., London: Cape, 1969.)

Lévi-Strauss, Claude (1962a) Le Totémisme aujourd'hui. Paris: Presses Universitaires de France. (English trans. Rodney Needham, Totemism, Boston, MA: Beacon Books, 1963.)

Lévi-Strauss, Claude (1962b) La Pensée sauvage. Paris: Plon. (English trans., The Savage Mind. Chicago: University of Chicago Press, 1969.)

Lévi-Strauss, Claude (1964) Le Cru et le cuit (Mythologiques, vol. I). Paris: Plon. (English trans. John Weightman and Doreen Weightman, The Raw and the Cooked: Introduction to a Science of Mythology. New York: Harper and Row, 1969.)

Lévi-Strauss, Claude (1966) Du Miel aux cendres (Mythologiques, vol. II). Paris: Plon. (English trans. John Weightman and Doreen Weightman, From Honey to Ashes, Introduction to a Science of Mythology, vol. 2. New York: Harper and Row, 1973.)

Lévi-Strauss, Claude (1967 [1949]) Les Structures élémentaires de la parenté, 2nd edn. Paris/Hague: Mouton. (Reprint, 2002.) (English trans. James Harle Bell, John Richard von Sturmer and Rodney Needham, The Elementary Structures of Kinship. Boston, MA: Beacon Press, 1969.)

Lévi-Strauss, Claude (1968) L'Origine des manières de table (Mythologiques, vol. III). Paris: Plon. (English trans., New York: Harper and Row, 1978.)

Lévi-Strauss, Claude (1971) L'Homme nu (Mythologiques, vol. IV). Paris: Plon. (English trans. John Weightman and Doreen Weightman, The Naked Man. New York: Harper and Row, 1981.)

Luhrmann, Tanya M. (1990) 'Our Master, Our Brother: Lévi-Strauss's Debt to Rousseau', Cultural Anthropology 5(4): 396-413.

Lyotard, Jean-François (1979) La Condition post-moderne: rapport sur le savoir. Paris: Minuit. (English trans. Geoff Bennington and Brian Massumi, The Postmodern Condition: A Report on Knowledge, Foreword by Frederic Jameson. Minneapolis: University of Minnesota Press, 1984.)

O'Hagan, Timothy (1978) 'Rousseau: Conservative or Revolutionary? A Critique of Lévi-Strauss', Critique of Anthropology 3(11): 19-38.

Scobie, David (1977) 'The Scientist, the Quester, and the Writer: Tristes Tropiques and Lévi-Strauss', Journal of the Anthropological Society of Oxford 8(3): 142-50.

Wittgenstein, Ludwig (1953) Philosophical Investigations. Oxford: Blackwell.

Wygant, Amy (1989) 'Goin' Home: Melody from the New World in Tristes Tropiques', Modern Language Notes 104(4): 899-912.

- Albert Doja was awarded his Doctorate in Social Anthropology in 1993 from the École des Hautes Études en Sciences Sociales in Paris and his post-doctoral degree 'Habilitation à Diriger des Recherches' in sociology and anthropology in 2004 from the University of Paris-5, Sorbonne. He has been a Research Fellow at the Institute of Folk Culture, Albanian Academy of Sciences, and in France at the National Centre for Scientific Research as a member of the Laboratory of Social Anthropology founded by Claude Lévi-Strauss. He has been a Lecturer in Social Anthropology at the Department of Sociology, University of Paris-8, and at the Department of Ethnology, University of Aix-en-Provence, France, as well as at the Department of Comparative and Applied Social Sciences, University of Hull, England. He is on the editorial board of Ethnologia Balkanica. Currently he is Senior Research Fellow at the College of Humanities, University of Limerick, Ireland, and Honorary Fellow at the Department of Anthropology, University College London. [email: albert.doja@ul.ie] 